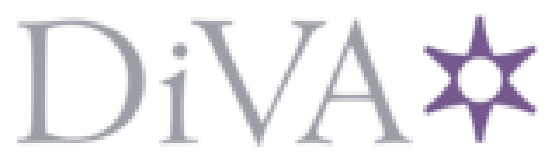

http://www.diva-portal.org

This is the published version of a paper published in Ecology.

Citation for the original published paper (version of record):

Kuglerova, L., Jansson, R., Ågren, A., Laudon, H., Malm-Renöfält, B. (2014)

Groundwater discharge creates hotspots of riparian plant species richness in a boreal forest stream network.

Ecology, 95(3): 715-725

http://dx.doi.org/10.1890/13-0363.1

Access to the published version may require subscription.

N.B. When citing this work, cite the original published paper.

Permanent link to this version:

http://urn.kb.se/resolve?urn=urn:nbn:se:umu:diva-88681 


\title{
Groundwater discharge creates hotspots of riparian plant species richness in a boreal forest stream network
}

\author{
Lenka Kuglerová, ${ }^{1,3}$ Roland Jansson, ${ }^{1}$ Anneli Ågren, ${ }^{2}$ Hualmar Laudon, ${ }^{2}$ And Birgitta Malm-RenöFält ${ }^{1}$ \\ ${ }^{1}$ Department of Ecology and Environmental Science, Umeå University, Umeå, Sweden \\ ${ }^{2}$ Department of Forest Ecology and Management, Swedish University of Agricultural Science, Umeå, Sweden
}

\begin{abstract}
Riparian vegetation research has traditionally focused on channel-related processes because riparian areas are situated on the edge of aquatic ecosystems and are therefore greatly affected by the flow regime of streams and rivers. However, due to their low topographic position in the landscape, riparian areas receive significant inputs of water and nutrients from uplands. These inputs may be important for riparian vegetation, but their role for riparian plant diversity is poorly known. We studied the relationship between the influx of groundwater $(\mathrm{GW})$ from upland areas and riparian plant diversity and composition along a stream size gradient, ranging from small basins lacking permanent streams to a seventh-order river in northern Sweden. We selected riparian sites with and without GW discharge using a hydrological model describing GW flow accumulation to test the hypothesis that riparian sites with GW discharge harbor plant communities with higher species richness. We further investigated several environmental factors to detect habitat differences between sites differing in GW discharge conditions. Vascular plant species richness was between $15 \%$ and $20 \%$ higher, depending on the spatial scale sampled, at riparian sites with GW discharge in comparison to non-discharge sites, a pattern that was consistent across all stream sizes. The elevated species richness was best explained by higher soil $\mathrm{pH}$ and higher nitrogen availability (manifested as lower soil $\mathrm{C} / \mathrm{N}$ ratio), conditions which were positively correlated with $\mathrm{GW}$ discharge. Base cations and possibly nitrogen transported by groundwater may therefore act as a terrestrial subsidy of riparian vegetation. The stable isotopes ${ }^{15} \mathrm{~N}$ and ${ }^{13} \mathrm{C}$ were depleted in soils from GW discharge compared to non-discharge sites, suggesting that GW inputs might also affect nitrogen and carbon dynamics in riparian soils. Despite the fact that many flows of water and nutrients reaching streams are filtered through riparian zones, the importance of these flows for riparian vegetation has not been appreciated. Our results demonstrated strong relationships between GW discharge, plant species richness and environmental conditions across the entire stream size gradient, suggesting that both river hydrology and upland inputs should be considered to fully understand riparian vegetation dynamics.
\end{abstract}

Key words: boreal forest; groundwater discharge; Krycklan catchment; riparian zone; soil nitrogen; soil pH; species richness; terrestrial subsidy; vascular plants.

\section{INTRODUCTION}

A major advance in ecology over the last decades has been the inclusion of how spatial relationships affect ecological patterns and processes (Legendre 1993, Hanski 1999, Leibold et al. 2004). The dispersal of animal and plant species among ecosystems in landscapes has been intensively studied, leading to better understanding of its consequences for species richness and food web structure (Wiens 2002). In contrast, the role of water flow across landscapes for patterns in species richness is not well understood. As an example, riparian ecosystems receive fluxes of water and nutrients from topographically higher terrestrial areas that maintain unique biogeochemical processes in riparian zones (Burt et al. 2002, Luke et al. 2007), but the role of

Manuscript received 25 February 2013; revised 20 June 2013; accepted 2 August 2013. Corresponding editor: M. W. Doyle.

${ }^{3}$ E-mail: lenka.kuglerova@emg.umu.se such subsidies (Fisher et al. 2004) for riparian plant diversity is poorly known.

While it has been recognized at least since the 1970s (Hynes 1975) that the structure of aquatic communities in streams is influenced by the river valley surrounding the stream channel, these issues have been overlooked by research on the factors structuring riparian vegetation. Available riparian research about factors controlling the diversity and composition of riparian vegetation is largely aimed towards stream-related processes, such as disturbance and stress caused by flooding (Nilsson 1987, Poff et al. 1997, Lite et al. 2005). Other studies have emphasized the importance of geomorphic processes and channel structure for riparian vegetation (Hupp and Osterkamp 1985, Polvi et al. 2011), and how stream flow affects hydrochory (Nilsson et al. 2010). A large body of literature has described the ability of riparian vegetation to buffer or filter inputs of material coming from uplands before they enter aquatic environ- 
ment (Hill 1996, Sabater et al. 2003, Grabs et al. 2010). This is not surprising given the position of riparian zones at the receiving end of groundwater (GW) and surface-material flows (Fisher et al. 2004, Jansson et al. 2007). However, a component largely missing in the literature is to what extent these flows affect the composition, dynamics, and richness of riparian vegetation.

These topics have been addressed in studies investigating non-riparian vegetation in boreal forest settings. For example, Giesler et al. (1998) found that GW flow affected the forest flora in a discharge area where a species-rich community of tall herbs replaced the species-poor dwarf shrubs typical of the boreal forest. Soil conditions were controlled by the influx of GW with higher amount of base cations and higher nitrogen availability (Giesler et al. 1998, Högberg et al. 2003). Similarly, Zinko et al. (2005) found more plant species in places predicted to be wetter as a result of topographically controlled GW flow. The species-rich wetter sites were dominated by species preferring high $\mathrm{pH}$, suggesting that $\mathrm{pH}$ was important for richness patterns (Zinko et al. 2005). While soil properties and consequently vegetation are primarily controlled by $\mathrm{GW}$ flows in forest settings (Zinko et al. 2005), the main driver of riparian vegetation is the hydrological regime of adjacent streams (Naiman and Décamps 1997). Thus, frequent disturbance and inundation in riparian zones may possibly mask the role of GW discharge. Further, the GW table in riparian zones is assumed to be generally close to the soil surface (Burt et al. 2002); therefore, GW flow paths might not affect the composition and species richness of riparian plant communities to such extent as documented for forest vegetation (Giesler et al. 1998, Zinko et al. 2005).

Preliminary results suggest that GW flows may also influence riparian vegetation along large rivers. Harner and Stanford (2003) showed that floodplain cottonwoods grew faster in gaining compared to losing reaches of a fifth-order river, whereas Jansson et al. (2007) found enhanced plant species richness in riparian $\mathrm{GW}$ discharge areas along two seventh-order rivers. Yet, the importance of GW discharge in riparian zones along headwater and medium-sized rivers is not known, although the total length of headwater streams far exceeds that of major rivers (Bishop et al. 2008). Despite the results of riparian studies along large rivers, such relationships between riparian vegetation and $\mathrm{GW}$ discharge along smaller stream sizes is uncertain due to the variation in how streams and rivers are set in the landscape. Large rivers are situated in valleys with long slopes, implying longer travelling times of $\mathrm{GW}$, which may therefore differ in composition from GW that has travelled downslope only short distances (Giesler et al. 1998), as along smaller streams.

Many other aspects of the relationship between GW flow and riparian plant species composition remain poorly understood. First, both higher soil pH (Zinko et al. 2005) and higher nutrient availability (Jansson et al. 2007) have been suggested as explanations for the positive correlation between GW discharge and plant species richness, but their relative importance is not known. Furthermore, previous riparian studies estimated GW fluxes by eye or topographic position only (Jansson et al. 2007). To move beyond what has previously been accomplished about how the terrestrial landscape affects the riparian vegetation, better understanding and modeling of GW flow paths is essential.

This study aimed to investigate the relationship between GW discharge and the structure of riparian vegetation across the landscape. First, we asked how riparian plant species richness and composition responded to upland-originating GW discharge, and how this relationship varied depending on stream size and soil conditions across a gradient of boreal forest stream sizes. Secondly, we asked to what extent relationships between riparian plant species composition and GW conditions could be explained by environmental conditions, such as soil characteristics $(\mathrm{pH}$ and nutrient availability) and geomorphologic features (aspect, slope). We hypothesized that riparian areas with GW discharge supported more diverse plant communities than riparian sites without the GW discharge. We further hypothesized that environmental conditions of sites with and without GW discharge differed and that the magnitude of such differences in, e.g., soil pH and nitrogen availability can explain differences in species composition.

\section{Methods \\ Site selection}

Forty riparian sites were established along streams varying in size in a boreal forest landscape in northern Sweden (Fig. 1a; see Plate 1). The majority of the sites (32) were placed along streams ranging in size from zeroorder basins (basins too small to harbor a permanent stream) to fourth-order streams in the Krycklan catchment (Fig. 1b), a tributary to the Vindel River. To extend the gradient of stream sizes beyond those available in the Krycklan catchment, four sites along the fifth-order Sävar River and four sites along the seventhorder Vindel River were included. All sites were placed within a radius of $25 \mathrm{~km}$ to keep regional climatic variation to a minimum. Furthermore, all sites, except those along the Sävar River, are part of the Vindel River system. Stream size selection was based on stream orders (Strahler 1957) and adjusted with regards to catchment area to ensure streams within a size class were similar in discharge (Appendix A). Therefore, the stream size classes used for size classification in this study roughly correspond to stream orders (Appendix A). The study area is divided by a major gemorphological boundary, the former highest postglacial coastline (FHC), formed by a pre-stage of the Baltic Sea about 10000 years ago. The FHC is situated $\sim 250 \mathrm{~m}$ above sea level in the catchment and divides areas with soils dominated by 


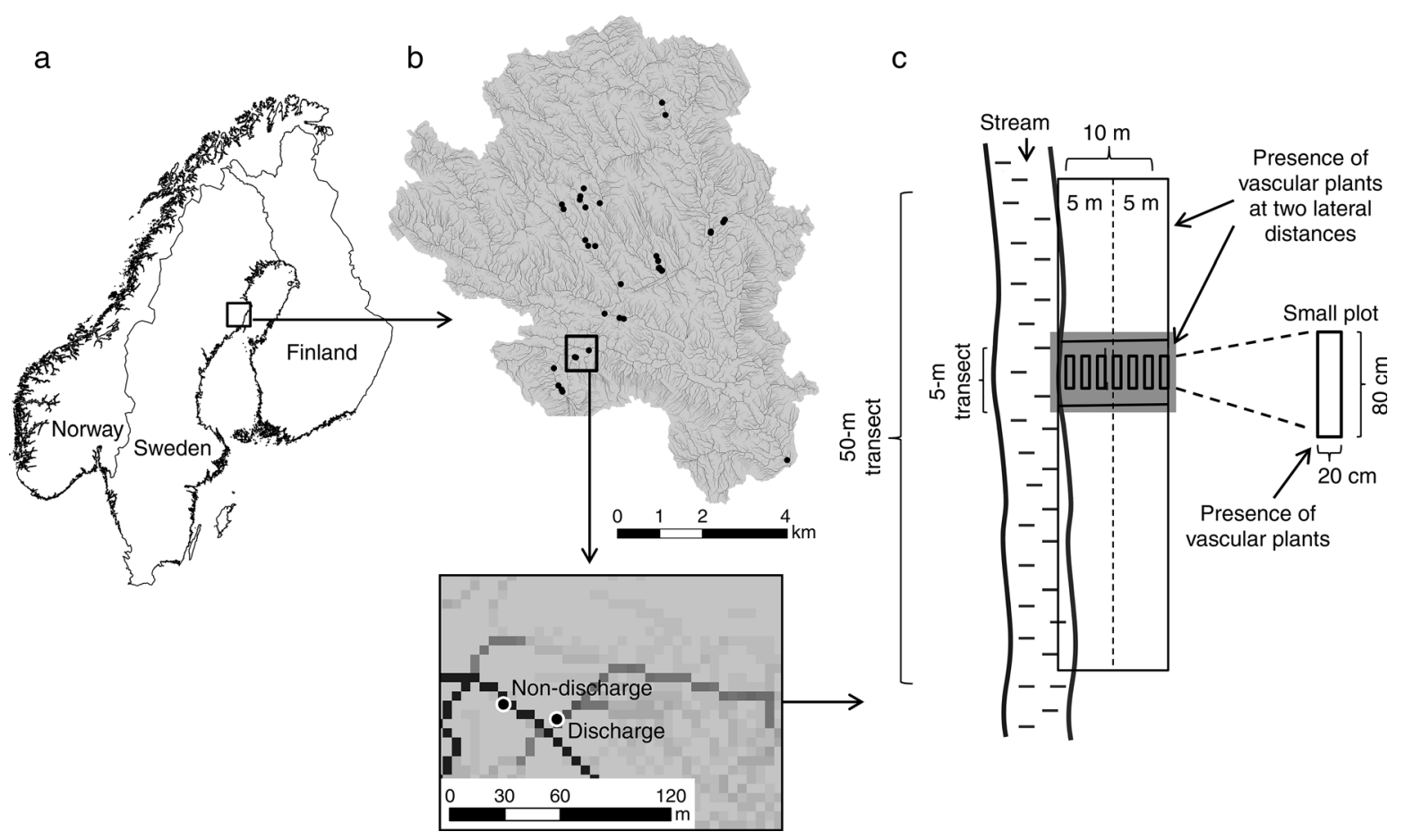

FIG. 1. The study area in Northern Sweden. (a) All 40 riparian sites were placed within a radius of $25 \mathrm{~km}$. (b) The majority of the sites (32) were placed along streams of different sizes (from zero-order basins to fourth-order streams) in the Krycklan catchment (black points). Pairs of sites were selected according to a groundwater $(\mathrm{GW})$ accumulation model of the Krycklan catchment (simplified on upper panel of [b]), 20 sites having GW discharge and 20 sites lacking discharge (non-discharge sites). Detail on panel (b) displays two selected sites along a first-order stream (darkest line), one having GW discharge, one being a non-discharge site, darker color of the flow path indicates higher values of GW accumulation according to the model. (c) Design of the plant surveys. At each site, a $5 \mathrm{~m}$ wide transect was established and all vascular plant species were recorded within 5- and 10-m lateral distance from the stream edge (giving $5 \times 5$ and $5 \times 10 \mathrm{~m}$ plots). Each 5 -m transect was placed at the river bank with GW conditions typical of the site (shaded area). The $5-\mathrm{m}$ transect was longitudinally extended to a $50 \mathrm{~m}$ wide transect, and the presence of vascular plant species in the $50-\mathrm{m}$ transect was recorded in the same manner as in the 5-m transect (giving $50 \times 5$ and $50 \times 10 \mathrm{~m}$ large plots). In the center of the 5$\mathrm{m}$ transect, several small plots $(20 \times 80 \mathrm{~cm})$ were placed at each $20-\mathrm{cm}$ interval in elevation above the stream.

unsorted glacial till above from sorted sedimentary deposits below the line. We selected streams in each size class in both parts of the catchment, although tilldominated catchments are represented only up to the third stream size class, given the lack of larger streams and rivers above the $\mathrm{FHC}$ in the region.

At each selected stream we established two riparian sites situated $<500 \mathrm{~m}$ apart. The selected pairs of sites were as similar as possible in terms of hydrological regime, land use, and surrounding vegetation, but differed in GW conditions. The first riparian site was placed at a stream bank with no GW discharge (nondischarge), while the other site was placed at a stream bank identified to have GW discharge of upland soil water ( $\mathrm{GW}$ discharge). Along the two largest rivers included in this study (fifth and seventh stream size classes), the site selection was based on visual evaluation of GW conditions due to unavailability of highresolution digital elevation model of their catchments. In the Krycklan catchment, the selection of GW discharge and non-discharge sites was based on a GW flow accumulation model (detail on Fig. 1b) and a topographic wetness index (TWI).
Flow accumulation was calculated from a digital elevation model $(D E M)$ with $5 \times 5 \mathrm{~m}$ resolution (Laudon et al. 2011). Prior to the calculations, manual corrections were made to the DEM based on field observations of the hydrology in difficult places (i.e., flat areas, ditches, stream/road crossings). These manual corrections created a flow-compatible DEM, from which downhill flow accumulation was calculated in ArcMap version 10 , using an algorithm routing water in eight directions (Jenson and Domingue 1988). GW discharge sites had GW accumulation areas between 0.15 and 6.5 ha in size, while at non-discharge sites, the area of GW accumulation was never larger than 0.03 ha. TWI was calculated as:

$$
\mathrm{TWI}=\ln \left(\frac{A}{\tan \beta}\right)
$$

where $A$ is the cumulative area $\left(\mathrm{m}^{2}\right)$ draining to each cell, calculated in ArcMap version 10.0 using the D8 algorithm, and $\beta$ is the slope of the cells expressed in radians (Beven and Kirkby 1979). TWI is based on the assumption that catchment topography controls soil wetness, and that soils in areas with steep slopes are well 
drained and soils in flat areas are poorly drained. This is a well-established method of locating wet areas in the landscape and many studies have shown a good correlation between field conditions and TWI. However, the study catchment partly consists of an old ice-river delta that is flat and dry, and sorting of the soil has a first-order control on soil drainage. Therefore, we used the TWI only as affirmative information for pairs of sites first selected according to the GW flow accumulation model. We did not measure soil moisture, but clear differences between GW discharge and non-discharge areas, confirming the model outcome, could be seen in the field.

\section{Vegetation survey}

To investigate whether species richness patterns persist across spatial scales, we recorded the presence of all vascular plant species at each site in five plot sizes nested within each other, going from $500 \mathrm{~m}^{2}$ to small 80 $\times 20 \mathrm{~cm}$ plots (Fig. 1c). At each site, we started with placing a $5 \mathrm{~m}$ wide transect and created a $5 \times 5 \mathrm{~m}$ plot adjacent to the stream. We laterally extended this plot by another $5 \mathrm{~m}$ further away from the stream, giving a 5 $\times 10 \mathrm{~m}$ plot (Fig. 1c). Longitudinally, we extended the 5$\mathrm{m}$ transect to a $50 \mathrm{~m}$ wide transect and investigated a 50 $\times 5 \mathrm{~m}$ area adjacent to the streams, and then laterally extended it to $50 \times 10 \mathrm{~m}$ plot (Fig. 1c). Within each $5-\mathrm{m}$ transect, $80 \times 20 \mathrm{~cm}$ plots were placed at every $20-\mathrm{cm}$ elevation interval, with the longer side facing the stream, starting at the stream edge that corresponded to summer low water levels (Fig. 1c). The highest elevation plot was placed in the transition between riparian and upland vegetation. At each pair of sites, we placed an equal number of plots. In each $80 \times 20 \mathrm{~cm}$ plot, we recorded all vascular plants species and also proportion of bare soil. With this design, we recorded plant species composition at five nested spatial scales at each site: small plots $(80 \times 20 \mathrm{~cm}), 25 \mathrm{~m}^{2}(5 \times 5 \mathrm{~m}), 50 \mathrm{~m}^{2}(10 \times 5$ $\mathrm{m}), 250 \mathrm{~m}^{2}(50 \times 5 \mathrm{~m})$, and $500 \mathrm{~m}^{2}(50 \times 10 \mathrm{~m})$. At the non-discharge sites, the entire 50-m transect lacked GW discharge, but at the GW discharge sites, the presence of discharging GW was predicted (and visually observed) mainly for the central 5-m transect, while beyond the 5$m$ transect the magnitude of discharge varied. The identification of plant species followed the taxonomy in Krok and Almquist (1994). In the following cases two or more species were treated as one taxon: Carex juncella+ Carex nigra, Callitriche spp., Hieracium spp., Hierochloë spp., Salix myrsinifolia + Salix phylicifolia, Sparganium spp., and Taraxacum spp.

\section{Environmental variables}

Three soil samples were collected using a T-handle soil auger with $2 \mathrm{~cm}$ diameter and 10-12 cm depth from the lowest, middle, and highest elevation $20 \times 80 \mathrm{~cm}$ plot at each site. Soil samples were placed in polyethylene bags and frozen at $-20^{\circ} \mathrm{C}$ for two months. They were then dried at $65^{\circ} \mathrm{C}$ for $48 \mathrm{~h}$, sieved with a $2-\mathrm{mm}$ mesh size and well mixed. To measure soil $\mathrm{pH}$, a subsample (10 $\mathrm{g}$ of mineral and $2 \mathrm{~g}$ of organic) of soils were suspended in 50 $\mathrm{mL}$ of deionized water and shaken for $15 \mathrm{~min}$. The $\mathrm{pH}$ of the slurry was measured by using a bench-top $\mathrm{pH}$ meter (Corning 220; Corning, Corning, New York, USA) the following day. Soil organic matter content was determined by loss of ignition as the mass difference between a dried soil sample (at $105^{\circ} \mathrm{C}$ ) and after $4 \mathrm{~h}$ of burning at $550^{\circ} \mathrm{C}$. Subsamples of dried and sieved soil were ground to a fine powder, and total carbon and nitrogen content and the signatures of the stable isotopes ${ }^{15} \mathrm{~N}$ and ${ }^{13} \mathrm{C}$ were measured with an elemental analyzer-isotope ratio mass spectrometer (Thermo Electron, Bremen, Germany).

The topography of each site was surveyed with spatial station (Trimble S3 Total Station; Trimble, Sunnyvale, California, USA) to determine the slope of each river bank. In order to measure canopy openness, a hemispherical photo from the central plot at each site was taken using a digital camera (Coolpix 4500; Nikon, Tokyo, Japan) equipped with a fisheye lens (Nikon FC$\mathrm{E} 8$, resulting in $182^{\circ}$ field of view) placed $10 \mathrm{~cm}$ above soil surface. The proportion of open sky at each site was determined using Gap light Analyzer software (Canham 1988). The aspect of each site was determined from the DEMs, and expressed as a degree deviation from south, i.e., sites oriented to the south had aspect 0 . All field surveys were conducted in June-August 2011.

\section{Statistical analyses}

To analyze patterns in vascular plant species richness, we used linear mixed-effect models (LMM). Data were analyzed using R (R Development Core Team 2011) with the R packages lme4 (Bates and Maechler 2009) and languageR (Baayen 2009) using lmer models with Poisson error structure because species richness represents counts. We fitted one model for the four larger spatial scales (i.e., from $25 \mathrm{~m}^{2}$ to $500 \mathrm{~m}^{2}$ ) which considered GW conditions (discharge vs. non-discharge), stream type (till vs. sediment), stream size class, and all two-way interactions as fixed effects, and stream identity as a random factor. At the $50-\mathrm{m}^{2}$ scale, aspect, bank slope, and canopy openness were also included as fixed effects, since these variables were measured at this spatial scale only. Small-plot scale $(20 \times 80 \mathrm{~cm})$ data were grouped into four groups with similar numbers of plots per site: zero-order basins, headwaters (stream size class 1-3), intermediate rivers (stream size class 4-5), and the Vindel River, and one LMM for each group, including also elevation above the stream, was fitted separately to detect patterns in plot species richness when stream size could be neglected. Selection of the best LMMs was based on likelihood ratio tests and on the lowest AIC (Akaike's information criterion) value. The significance of final model parameters was estimated by Markov chain Monte Carlo (MCMC) estimation. This approach is more appropriate for testing mixed effect models compared to the regular $t$ distribution or $F$ 

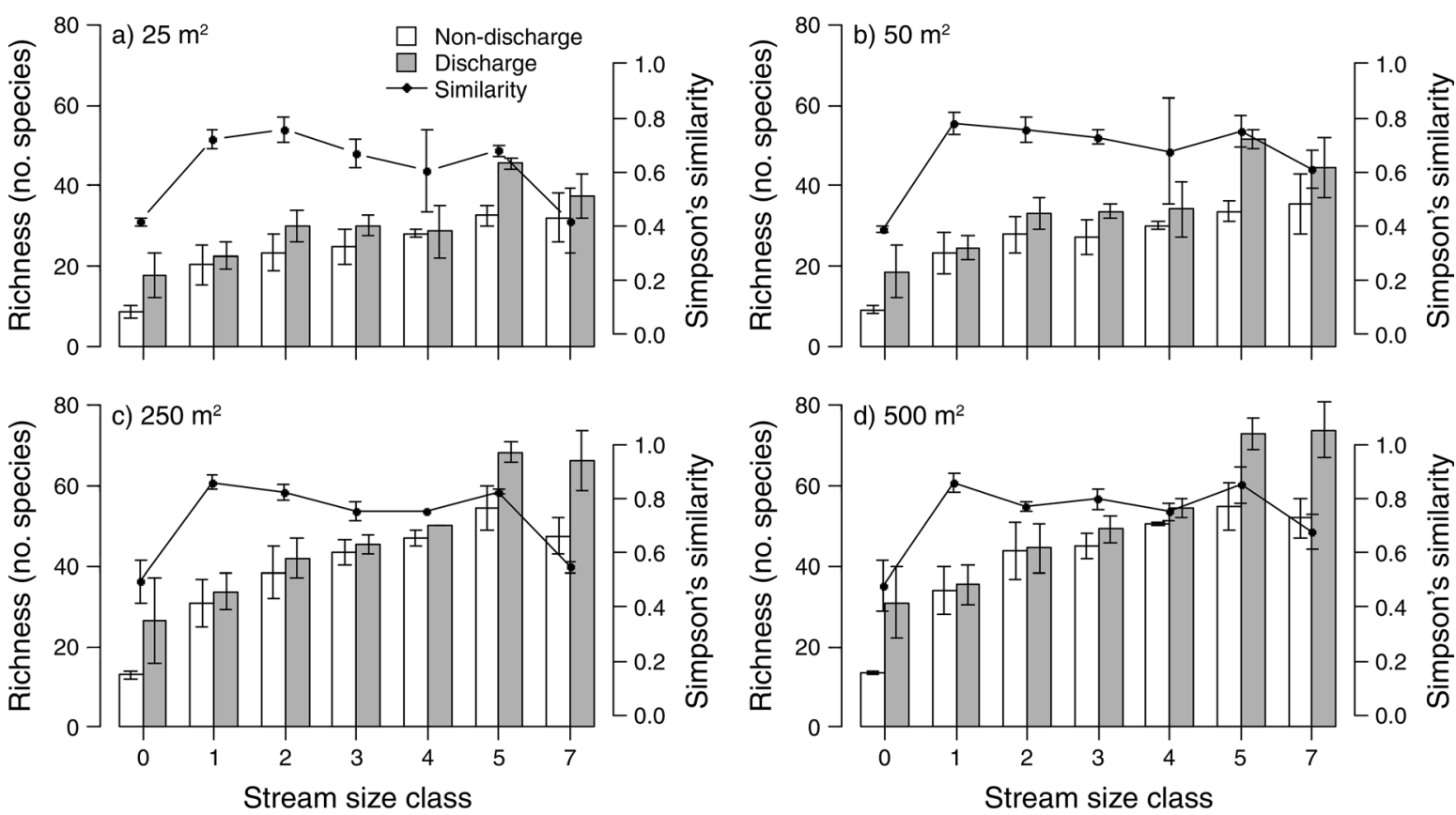

FIG. 2. Vascular plant species richness (mean $\pm \mathrm{SE}$ ) for each stream size class for 40 riparian sites compared between GW discharge (gray bars) and non-discharge sites (white bars), and displayed separately for riparian plots of different sizes: (a) $25 \mathrm{~m}^{2}$, (b) $50 \mathrm{~m}^{2}$, (c) $250 \mathrm{~m}^{2}$, and (d) $500 \mathrm{~m}^{2}$. Linear mixed-effect model fitted separately for each spatial scales revealed significantly higher plant species richness at GW discharge sites at all spatial scales $(P<0.05)$. The index of Simpson's similarity (mean $\pm \mathrm{SE})$ for pairs of GW discharge and non-discharge sites averaged for each stream size class is displayed on the right-hand $y$-axis.

distribution (Baayen et al. 2008). Reported $P$ values are the results of MCMC simulations significant at $\alpha=0.05$.

To test for differences in environmental conditions among sites, we fitted a LMM (assuming Gaussian distributed errors) to each soil and environmental variable $(\mathrm{pH}$, organic content, carbon $[\mathrm{C}]$, nitrogen $[\mathrm{N}], \mathrm{C} / \mathrm{N}$ ratio, isotopes, percentage of bare soil) with GW conditions, stream type, stream size, and elevation above the stream edge as fixed effects and stream identity as a random factor. All two-way interactions were included in the full models. We used ANOVA (two-way also accounting for the stream type, i.e., sedimentary vs. till) to investigate differences in aspect, slope of the river banks, and canopy openness between GW discharge and non-discharge sites. Prior to analyses, canopy openness was log-transformed and slope was square-root arcsine transformed to fulfill the assumption of normality.

We used path analysis (Wright 1921) to assess the relative importance of various environmental variables for riparian plant species richness $\left(50-\mathrm{m}^{2}\right.$ plot scale). Specifically, we evaluated the relative importance of soil $\mathrm{pH}$ and $\mathrm{C} / \mathrm{N}$ ratio for species richness, assuming $\mathrm{pH}$ and $\mathrm{C} / \mathrm{N}$ ratio were controlled by $\mathrm{GW}$ conditions. To allow GW flow to be a continuous variable, we restricted the analysis to the sites in the Krycklan catchment for which absolute values of GW discharge at each site were predicted by the flow accumulation model. The average of soil samples from the middle- and high-elevation plots were used for $\mathrm{pH}$ and $\mathrm{C} / \mathrm{N}$ ratio values. $\mathrm{C} / \mathrm{N}$ ratio was square-root and $\mathrm{GW}$ accumulation was log-transformed prior to the analyses. We also included stream size and stream type (sedimentary vs. till) as variables affecting $\mathrm{pH}, \mathrm{C} / \mathrm{N}$ ratio, and species richness in the path analysis.

We used Ellenberg indicator values (Ellenberg et al. 1992) for moisture, $\mathrm{pH}$, and nitrogen availability to assess differences in the tolerance or adaptation of species to these factors among sites. Median Ellenberg values were estimated for each $50-\mathrm{m}^{2}$ plot and compared by two-way ANOVA between sites differing in GW conditions. Finally, Simpson's index of similarity (the proportion of all species shared between both sites divided by all species found at the more species poor site) was used to investigate how similar pairs of sites differing in GW conditions were. We calculated the similarity for the four larger spatial scales (i.e., $25 \mathrm{~m}^{2}$ to $500 \mathrm{~m}^{2}$ ) and for each stream size separately. All ANOVAs were performed with $\mathrm{R}$ ( $\mathrm{R}$ Development Core Team 2013).

\section{RESUlTS}

\section{Species richness}

GW discharge sites harbored significantly more plant species than non-discharge sites at all spatial scales $\left(\mathrm{LMM}\right.$, for $25-\mathrm{m}^{2}$ plots, $P_{\mathrm{MCMC}}=0.0009, \mathrm{df}=19 ; 50$ $\mathrm{m}^{2}, P_{\mathrm{MCMC}}=0.0003, \mathrm{df}=16 ; 250 \mathrm{~m}^{2}, P_{\mathrm{MCMC}}=0.003$, $\mathrm{df}=19 ; 500 \mathrm{~m}^{2}, P_{\mathrm{MCMC}}=0.0015, \mathrm{df}=19 ;$ Figs. 2 and 3 ). This pattern was observed for all stream sizes and was 


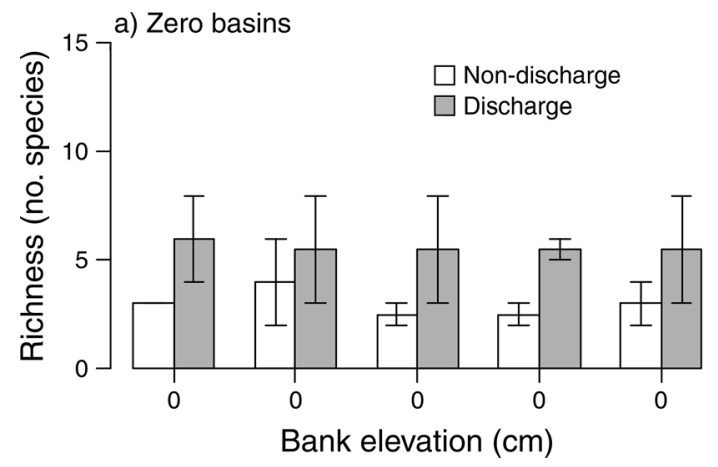

c) Intermediate rivers

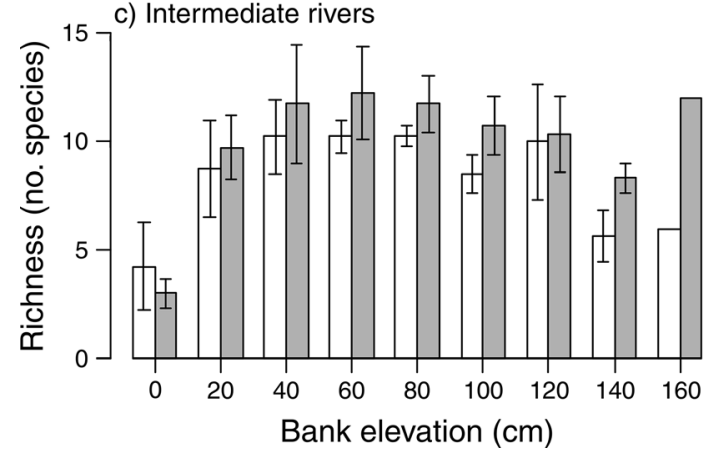

b) Headwaters

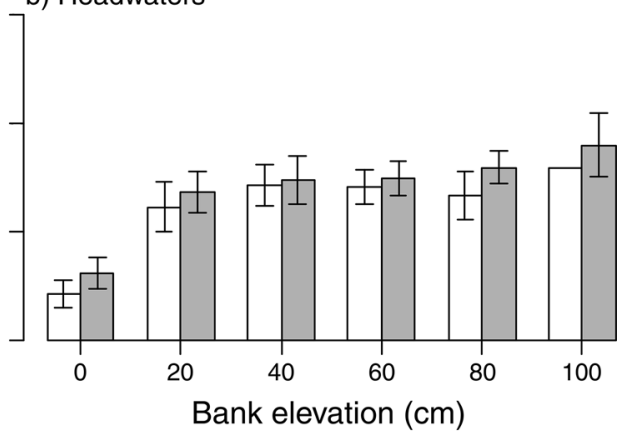

d) Vindel River

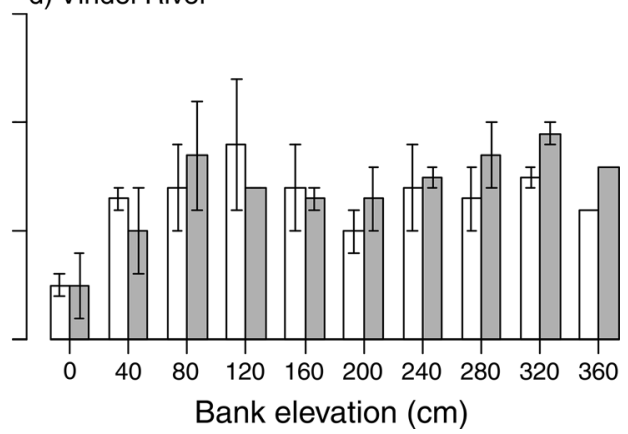

FIG. 3. Vascular plant species richness (mean \pm SE) for $20 \times 80 \mathrm{~cm}$ plots vs. bank elevation compared between GW discharge (gray bars) and non-discharge (white bars) sites displayed separately for four groups of stream sizes: (a) zero-order basins (lacking a stream), (b) headwaters (stream size class 1-3), (c) intermediately sized rivers (stream size class 4 and 5), and (d) the Vindel River (stream size class 7). Along headwaters and intermediate rivers, plot species richness was significantly higher at GW discharge sites $(P<0.05)$. At zero-order basin sites, the higher plot species richness was detected only at sedimentary sites. No effect of GW conditions was detected for sites along the Vindel River for the $20 \times 80 \mathrm{~cm}$ plots $(P>0.05)$.

consistent for both sedimentary and till streams, even though we found generally higher plant species richness along sedimentary than till streams (LMM, for $25-\mathrm{m}^{2}$ plots, $P_{\mathrm{MCMC}}=0.038, \mathrm{df}=19 ; 50 \mathrm{~m}^{2}, P_{\mathrm{MCMC}}=0.021, \mathrm{df}$ $=16 ; 250 \mathrm{~m}^{2}, P_{\mathrm{MCMC}}=0.0003, \mathrm{df}=19 ; 500 \mathrm{~m}^{2}, P_{\mathrm{MCMC}}$ $=0.003, \mathrm{df}=19$; Appendix B). Differences in species richness between sites differing in GW conditions were larger at smaller spatial scales $\left(25 \mathrm{~m}^{2}\right.$ and $\left.50 \mathrm{~m}^{2}\right)$, with GW discharge sites having, on average, $20 \%$ more species than non-discharge sites. At the two larger scales $\left(250 \mathrm{~m}^{2}\right.$ and $\left.500 \mathrm{~m}^{2}\right)$, the difference was $15 \%$. We also observed that differences in species richness between pairs of GW discharge and non-discharge sites increased with increasing stream size, regardless of the spatial scale (Fig. 2). Aspect and slope of the river bank did not show any significant relationship with vascular plant species richness (LMM, aspect, $P_{\mathrm{MCMC}}=0.65, \mathrm{df}=16$; slope, $\left.P_{\text {MCMC }}=0.97, \mathrm{df}=16\right)$ and were omitted from the final model. Canopy openness had a significant negative relationship with plant species richness, but this was found to be due to canopy openness being correlated with stream size $(r=0.36, P=0.03$, Pearson productmoment correlation), and therefore, canopy openness was omitted.

In the small plots $(20 \times 80 \mathrm{~cm})$, we detected higher species richness at GW discharge than at non-discharge sites for headwater streams (for stream size class 1-3, $P_{\mathrm{MCMC}}=0.001, \mathrm{df}=103$ ) and intermediate rivers (for stream size class $4-5, P_{\mathrm{MCMC}}=0.04, \mathrm{df}=55$; Fig. 3 ). We found no relationship between $\mathrm{GW}$ discharge and species richness for the Vindel River small-plot data. At the zero-order basins, the positive relationship between GW discharge and small-plot species richness was found only at the sedimentary sites $\left(P_{\mathrm{MCMC}}=0.006\right.$, $\mathrm{df}=13)$. We further found significant positive relationships between small-plot species richness and elevation above the stream (for headwaters, $P_{\mathrm{MCMC}}<0.0001$, df $=103$; intermediate rivers, $P_{\mathrm{MCMC}}=0.002, \mathrm{df}=55$; Vindel River, $P_{\mathrm{MCMC}}=0.02$, df $=34$ ), but this was primarily caused by few or no plants occurring at the lowest elevation plots at the edge of the streams (Fig. 3).

Path analysis showed that the increase in riparian species richness with increasing GW flow accumulation (effect coefficient $p=0.37$ ) was better explained by the indirect effects of $\mathrm{GW}$ via soil $\mathrm{pH}$ (path coefficient $p=$ $0.20)$ and $\mathrm{C} / \mathrm{N}$ ratio $(p=0.11)$, rather than the direct effect of discharging GW ( $p=0.05$; Appendix C).

\section{Community composition}

In total, we found 175 species of vascular plants on all 40 sites combined. Considering only the $50-\mathrm{m}^{2}$ spatial scale, we found that 39 of all the species $(22 \%)$ occurred 

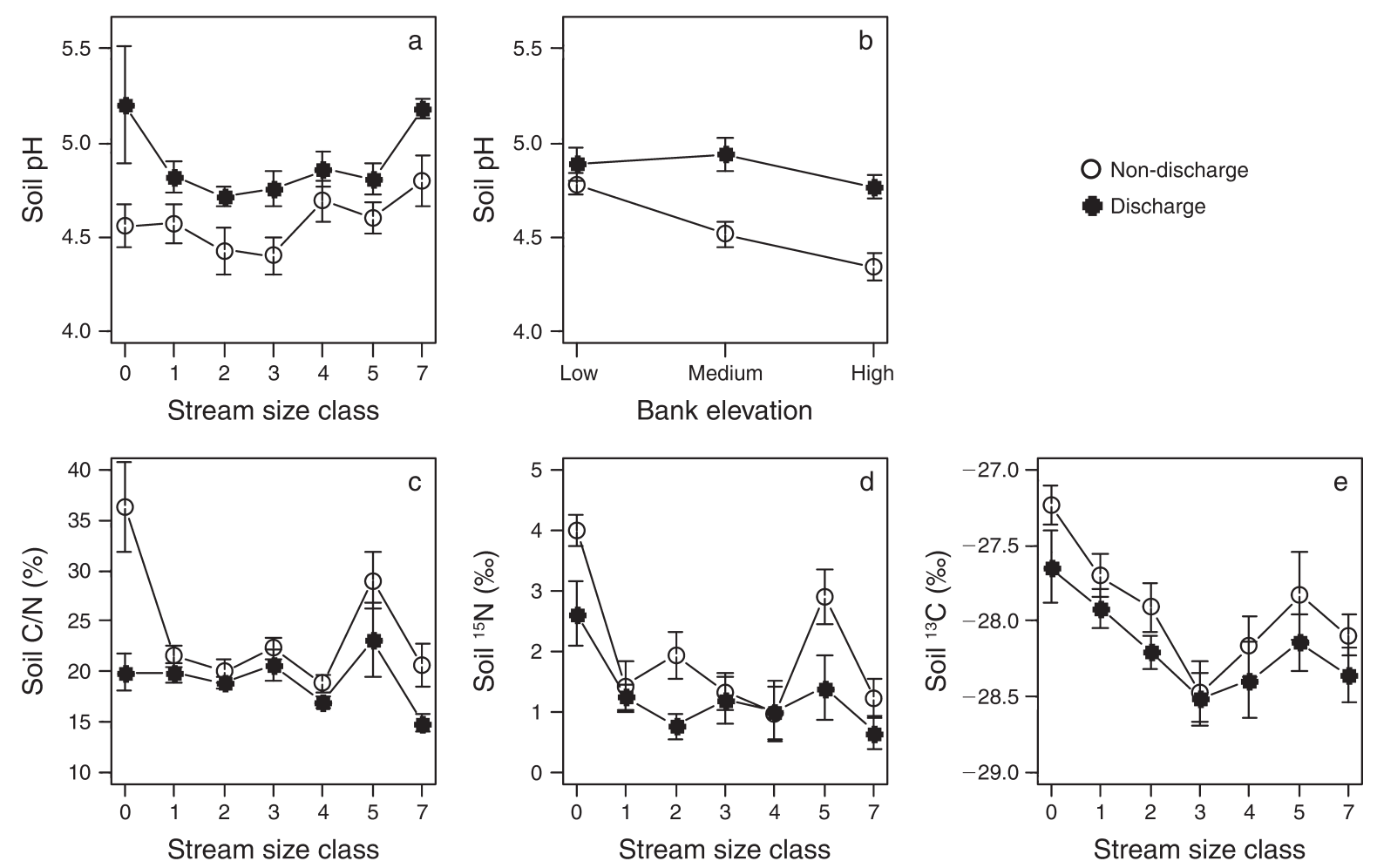

FIG. 4. Comparison of soil variables between riparian sites differing in GW conditions. Soil pH (mean \pm SE) compared between GW discharge (solid circles) and non-discharge (open circles) sites for (a) all stream size classes and (b) depending on elevation in the riparian zone. Low, medium, and high bank elevations represent the $80 \times 20 \mathrm{~cm}$ plots closest to the stream, in the middle, and farthest, respectively. (c) Values (mean $\pm \mathrm{SE}$ ) of $\mathrm{C} / \mathrm{N}$ ratios (shown as percentages) and content of the stable isotopes (d) $\delta^{15} \mathrm{~N}$ and (e) $\delta^{13} \mathrm{C}$ in riparian soils are displayed for all stream size classes and compared between $\mathrm{GW}$ discharge (solid circles) and non-discharge (open circles) sites. Soil $\mathrm{pH}$ was significantly higher at $\mathrm{GW}$ discharge sites, while for the three latter parameters, higher values were detected at non-discharge sites by using linear mixed-effect models (Table 2).

only at the riparian sites with GW discharge. In contrast, we found 16 species (10\%) occurring only at the non-discharge sites. Ellenberg indicator values for moisture were significantly higher at $\mathrm{GW}$ discharge than non-discharge sites (two-way ANOVA, $P=0.004, F_{1,37}$ $=9.332$ ), whereas we found no difference for $\mathrm{pH}$ and nitrogen availability $(P>0.05)$. Simpson's similarity between pairs of sites differing in GW conditions ranged between $40 \%$ and $80 \%$ depending on the stream size and spatial scale (Fig. 2), and a trend of decreasing similarity with increasing stream size was detected (although zeroorder basins were most dissimilar).

\section{Environmental variables}

Soil $\mathrm{pH}$ was higher at sites with GW discharge at all stream sizes (Fig. 4a), and a linear mixed-effect model revealed a significant positive relationship between GW discharge and soil $\mathrm{pH}$ independent of stream size (Table 1). Furthermore, at $\mathrm{GW}$ discharge sites the $\mathrm{pH}$ of riparian soils was similar along all elevations above the stream, whereas at the non-discharge sites, the $\mathrm{pH}$ decreased with increasing elevation (significant interaction between GW condition and elevation in the final LMM, $P_{\text {MCMC }}=0.005, \mathrm{df}=94$; Fig. $\left.4 \mathrm{~b}\right)$. We found no differences in organic content of riparian soils between sites differing in GW conditions (Table 1). Overall, $\mathrm{C} / \mathrm{N}$ ratio and proportions of both ${ }^{15} \mathrm{~N}$ and ${ }^{13} \mathrm{C}$ in riparian soils were significantly lower at the GW discharge sites (Fig. 4c-e, Table 1). We found no significant difference in canopy openness and aspect of river banks between pairs of GW discharge and non-discharge sites (Table 1). Finally, bank slopes at discharge sites were significantly gentler than the slopes of non-discharge sites regardless of stream size or stream type (Table 1). In addition, we found that some of the environmental variables $\left(\mathrm{pH}, \mathrm{C} / \mathrm{N}\right.$, total $\mathrm{N}$, total $\mathrm{C},{ }^{13} \mathrm{C}$, percentage of bare soil) differed significantly between sites along the till and sedimentary streams (Appendix D).

\section{Discussion}

Our results demonstrated that riparian sites with GW discharge are hotspots of plant species richness across the landscape. The strong relationships between GW discharge and riparian environmental conditions (i.e., higher soil $\mathrm{pH}$, and lower $\mathrm{C} / \mathrm{N}$ ratio and proportions of ${ }^{15} \mathrm{~N}$ and ${ }^{13} \mathrm{C}$ ) suggest that upland-originating $\mathrm{GW}$ might act as terrestrial subsidy by providing base cations and nutrients affecting the riparian habitat in important ways. Enhanced species richness at GW discharge sites was found across the entire stream size gradient studied, 
TABLE 1. Summary of all environmental variables (mean $\pm \mathrm{SE}$ ) measured at 40 riparian sites and statistical differences between pair of sites differing in groundwater (GW) discharge conditions (presence or absence).

\begin{tabular}{|c|c|c|c|c|c|c|}
\hline Variable & GW discharge & Non-discharge & Estimate & $P$ & $\mathrm{df}$ & $F$ \\
\hline \multicolumn{7}{|l|}{ LMMs } \\
\hline $\mathrm{pH}$ & $4.9 \pm 0.05$ & $4.6 \pm 0.05$ & 0.42 & $>0.0001$ & 94 & \\
\hline Organic content (\%) & $0.20 \pm 0.03$ & $0.17 \pm 0.03$ & -0.03 & 0.8214 & 98 & \\
\hline $\mathrm{C} / \mathrm{N}$ ratio $(\%)$ & $19.3 \pm 0.6$ & $23.4 \pm 0.9$ & -0.14 & 0.0001 & 91 & \\
\hline Total N (\%) & $0.46 \pm 0.08$ & $0.35 \pm 0.06$ & 0.13 & 0.3320 & 93 & \\
\hline Total C (\%) & $9.2 \pm 1.8$ & $8.5 \pm 1.5$ & -0.01 & 0.9268 & 93 & \\
\hline$\delta^{13} \mathrm{C}(\%)$ & $-28.2 \pm 0.1$ & $-28.0 \pm 0.1$ & -0.21 & 0.0092 & 92 & \\
\hline$\delta^{15} \mathrm{~N}(\%)$ & $1.2 \pm 0.2$ & $1.9 \pm 0.2$ & -0.24 & 0.0072 & 95 & \\
\hline Bare soil $(\%)$ & $16.8 \pm 2.2$ & $22.0 \pm 2.4$ & -0.06 & 0.0496 & 216 & \\
\hline \multicolumn{7}{|l|}{ ANOVA } \\
\hline Slope $(\mathrm{m} / \mathrm{m})$ & $18.0 \pm 2.9$ & $37.3 \pm 5.1$ & -0.14 & 0.0046 & 2,37 & 9.113 \\
\hline Aspect $\left({ }^{\circ}\right)$ & $62.6 \pm 11.6$ & $89.7 \pm 9.0$ & -27.15 & 0.0715 & 2,37 & 3.443 \\
\hline Canopy openness (\%) & $20.0 \pm 1.4$ & $19.7 \pm 1.4$ & 0.01 & 0.8668 & 3,36 & 0.029 \\
\hline
\end{tabular}

Notes: Statistical analysis for all soil variables and the percentage of bare soil were performed by using linear mixed-effect models (LMMs), and the $P$ values are results of Markov chain Monte Carlo simulations. Degrees of freedom (df) in the LMMs were calculated as the total amount of observation minus all the factors (fixed + random). Differences in slope, aspect, and canopy openness were detected by analysis of variance (two-way ANOVA) with corresponding degrees of freedom (df) and $F$ statistic. Boldface values were statistically significant at $\alpha=0.05$.

from zero-order basins to the seventh-order river, demonstrating a general pattern regardless of stream properties. Furthermore, the positive relationship between riparian plant species richness and GW discharge was consistent across all spatial scales sampled. Based on these results, we propose that holistic approaches including both river hydrology and upland inputs should be considered to fully understand the dynamics of riparian vegetation.

We demonstrated that adjacent riparian zones, represented by pairs of GW discharge and nondischarge sites, are spatially heterogeneous in GW conditions. This is in opposition to the common assumption that all riparian zones, having shallow GW tables, are generally discharge areas (Burt et al. 2002), especially those along small streams (Shoutis et al. 2010). Importantly, we identified sites of riparian GW discharge from models describing downslope GW accumulation. Recently, advanced models for predicting GW flow paths have become common in forested landscapes (Kopecký and Čížková 2010), but have been rarely used for locating GW discharge in riparian zones (Grabs et al. 2010, Lyon et al. 2011). As mentioned, sites along the two largest rivers (fifth and seventh stream size class) were selected based on visual evaluation of GW conditions only. Along these rivers, we found the largest differences in species richness between pairs of GW discharge and non-discharge sites. However, GW discharge predicted by the model (Krycklan catchment) was less prominent when evaluated visually. Therefore, the GW discharge sites selected by eye may have higher absolute values of GW accumulation than the sites selected by the model, preventing inferences about the magnitude of effect of GW discharge on vegetation across stream sizes.

Riparian GW discharge sites differed from nondischarge sites in a range of environmental variables, which can be explained as consequence of GW input. We found higher soil $\mathrm{pH}$ and lower soil $\mathrm{C} / \mathrm{N}$ ratios, resulting in more available $\mathrm{N}$ and more productive habitats on the GW discharge sites. This matches previous studies in boreal forest settings, where GW discharge sites were documented to have higher soil $\mathrm{pH}$ (as a result of enrichment by base cations as the GW flows through the soil profile), higher nutrient availability, and/or lower $\mathrm{C} / \mathrm{N}$ ratios in comparison to recharge locations (Giesler et al. 1998, Högberg et al. 2003, Zinko et al. 2006). The differences in soil processes between pairs of GW discharge and non-discharge sites in our study were also reflected by enrichment of ${ }^{13} \mathrm{C}$ and ${ }^{15} \mathrm{~N}$ at the non-discharge sites, possibly indicating faster mineralization of organic matter, different end products of the nitrogen cycle, or discrimination against the heavy isotopes when nitrogen is taken up by plants (Högberg 1997).

Why was GW discharge in riparian zones positively correlated with plant species richness across all stream sizes? Factors typical of GW discharge sites and which have been positively associated with plant species richness are high soil $\mathrm{pH}$, high nitrogen availability (expressed, e.g., as low soil $\mathrm{C} / \mathrm{N}$ ratio), or continuous supply of seeping water (Giesler et al. 1998, Zinko et al. 2005, Jansson et al. 2007). According to the path analysis, any direct effect of seeping GW on species richness was weak, in comparison with the indirect effects of $\mathrm{GW}$ via soil $\mathrm{pH}$ and $\mathrm{C} / \mathrm{N}$ ratio. The causal chain-GW discharge increasing soil $\mathrm{pH}$ resulting in higher species richness - was stronger than the path via $\mathrm{C} / \mathrm{N}$ ratio (Appendix $\mathrm{C}$ ). In boreal forests of Fennoscandia, having generally acidic soils, soils with higher $\mathrm{pH}$ have been documented as preferred habitats for many plant species (Giesler et al. 1998, Zinko et al. 2005) because more species are adapted to high soil $\mathrm{pH}$ as a result of immigration history after the last glaciation 
(Zinko et al. 2006). However, previous riparian studies have found weak support for positive correlations between soil $\mathrm{pH}$ and plant species richness. Jansson et al. (2007) found higher species richness at GW discharges sites along both the regulated Ume and the free-flowing Vindel Rivers, but soil $\mathrm{pH}$ was positively correlated with GW discharge only in the Ume River sites. Renöfält et al. (2005) found a negative relationship between riparian species richness and soil $\mathrm{pH}$ for the Vindel River. The differences in plant species richness$\mathrm{pH}$ relationships among studies can be explained by differences in the range of soil $\mathrm{pH}$ gradient sampled. The pH range sampled by Jansson et al. (2007) was small $(\mathrm{pH}=4.5$ to 5.0$)$, and the range of soil $\mathrm{pH}$ values recorded by Renöfält et al. (2005) $(\mathrm{pH}=5.2$ to 6.1) was likely on the decreasing end of the unimodal $\mathrm{pH}$-species richness relationship detected for forest plant communities (Dupré et al. 2002). In the present study, the soil $\mathrm{pH}$ range was relatively large $(\mathrm{pH}=3.7$ to 6.0$)$ and suggested a positive relationship with vascular plant species richness. Another potential explanation for high diversity at GW discharge sites is higher availability of nitrogen, the most limiting plant nutrient in boreal terrestrial environments (Giesler et al. 1998), expressed as lower $\mathrm{C} / \mathrm{N}$ ratio in our study. Increases in $\mathrm{N}$ on sites with $\mathrm{GW}$ accumulation have been documented in both forest and riparian studies (Giesler et al. 1998, Högberg et al. 2003, Jansson et al. 2007), the mechanism suggested being nutrient enrichment of GW as it travels downslope, and faster $\mathrm{N}$ mineralization and turnover at discharge sites providing more $\mathrm{N}$ available to plants. In this study, no measurements of GW biochemistry were conducted; therefore, the mechanism driving the lower $\mathrm{C} / \mathrm{N}$ ratio at $\mathrm{GW}$ discharge sites remains uncertain.

Although the direct effect of seeping GW was weak in the path analysis, the significantly higher Ellenberg values for moisture of species found at GW discharge sites suggested that continuous water supply also affects the abundance and zonation of riparian plant species. In riparian zones lacking GW discharge, the GW table fluctuates in response to water level fluctuations in the adjacent stream (Burt et al. 2002). The GW discharge locations used in this study are the product of geomorphologic development since the last glaciation resulting in a relatively consistent supply of uplandoriginating soil water, although the volume of received GW flow may fluctuate seasonally (L. Kuglerová, personal observation). The fact that riparian areas with GW discharge receive this terrestrial water independently of stream water could potentially make these areas more tolerant to climate-driven hydrological changes such as lowering of the spring flood peaks and lower summer flows (Andréasson et al. 2004). These changes in stream hydrology are expected to result in more narrow riparian zones, shifts in the position of vegetation belts, and potential loss of some plant species (Ström et al. 2012). GW discharge in riparian zones may mitigate these risks by having water supply regardless

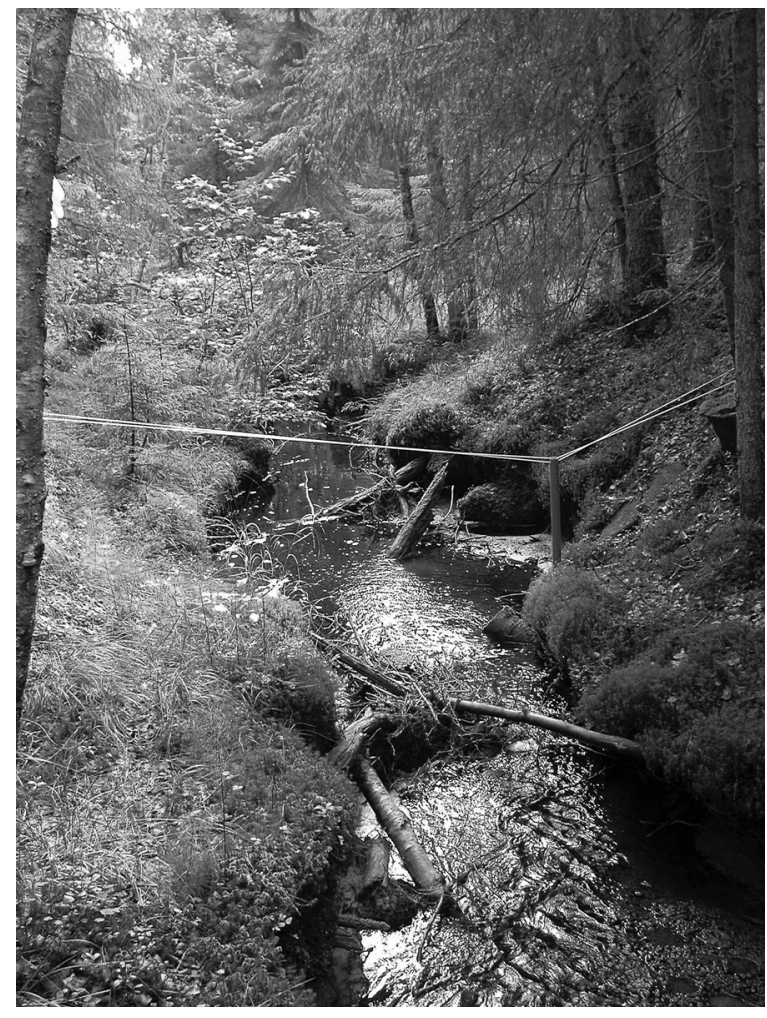

Plate 1. Non-discharge riparian site (right-hand bank) along a third-order stream in the sediment part of the Krycklan catchment. Note the water level logger installed in the PVC tube in the stream. Photo credit: L. Kuglerová.

the flow regime of the adjacent streams, a proposition supported by riparian vegetation belts being wider on GW discharge than corresponding non-discharge sites (as demonstrated by the $20 \times 80 \mathrm{~cm}$ plot richness results; Fig. 3). Therefore, GW flow paths should be also taken into account when forecasting responses of riparian vegetation to climate change, a topic where attention has almost exclusively been on stream hydrology (Merritt et al. 2010, Ström et al. 2012).

Knowledge of GW discharge conditions in riparian zones may have potentially large implications for forestry, conservation, or restoration management. First, the ongoing debate about ecologically effective widths of riparian buffer strips in protecting riparian and aquatic ecosystems suggests that rather than trying to set a single, optimal width, riparian buffers could be adjusted with respect to local conditions (Richardson et al. 2012). Allowing wider riparian buffer strips around GW discharge areas may help to reduce the impact of catchment management on riparian ecosystems in places with high plant species diversity. Second, a dramatic increase in stream restoration activities has occurred worldwide over the past few decades. However, funding for stream restoration is often limited and stream restoration is performed on selected reaches rather than 
whole streams or catchments (Bernhardt and Palmer 2011). We propose that stream restoration, as well as conservation actions, should be aimed towards river reaches with high GW flow accumulation given their importance for biodiversity at the scale of landscapes, and their potential capacity as riparian habitats more tolerant to climate-driven hydrological changes. Finally, we have demonstrated that GW flow accumulation models could be used as a tool for locating biodiversity hotspots in riparian corridors and potentially for identifying sites in need of protection against riparian exploitation, such as logging or development.

\section{ACKNOWLEDGMENTS}

We thank Johan Lingegård, Julia Jansson, and Isak Lindmark for helping with the fieldwork and two anonymous reviewers for valuable comments on the manuscript. Funding was provided by the Swedish Research Council Formas (to R. Jansson). We also acknowledge Mistra Future Forest and Formas Forwater for co-supporting this work.

\section{Literature Cited}

Andréasson, J., S. Bergström, B. Carlsson, L. P. Graham, and G. Lindström. 2004. Hydrological change: climate change impact simulations for Sweden. Ambio 33:228-234.

Baayen, R. H. 2009. languageR: data sets adn functions with "analysing linguistic data: a practical introduction to statistics”. R package version 0.955. R Foundation for Statistical Computing, Vienna, Austria.

Baayen, R. H., D. J. Davidson, and D. M. Bates. 2008. Mixedeffects modeling with crossed random effects for subjects and items. Journal of Memory and Language 59:390-412.

Bates, D. M., and M. Maechler. 2009. lmer4: linear mixedeffects models using S4 classes. R package version 0.99937532. R Foundation for Statistical Computing, Vienna, Austria.

Bernhardt, E. S., and M. A. Palmer. 2011. River restoration: the fuzzy logic of repairing reaches to reverse catchment scale degradation. Ecological Applications 21:1926-1931.

Beven, K. J., and M. J. Kirkby. 1979. A physically based, variable contributing area model of basin hydrology/Un modèle à base physique de zone d'appel variable de l'hydrologie du bassin versant. Hydrological Sciences Bulletin 24: 43-69.

Bishop, K., I. Buffam, M. Erlandsson, J. Fölster, H. Laudon, J. Seibert, and J. Temnerud. 2008. Aqua Incognita: the unknown headwaters. Hydrological Processes 22:1239-1242.

Burt, T. P., et al. 2002. Water table fluctuations in the riparian zone: comparative results from a pan-European experiment. Journal of Hydrology 265:129-148.

Canham, C. D. 1988. An index for understory light levels in and around canopy gaps. Ecology 69:1634-1638.

Dupré, C., C. Wessberg, and M. Diekmann. 2002. Species richness in deciduous forests: Effects of species pools and environmental variables. Journal of Vegetation Science 13: $505-516$.

Ellenberg, H., H. E. Webber, R. Dull, V. Wirth, W. Werner, and D. Paulissen. 1992. Zeigerwerte von Pflanzen in Mitteleuropa. Scripta Geobotanica 18:1-258.

Fisher, S. G., R. A. Sponseller, and J. B. Heffernan. 2004. Horizons in stream biogeochemistry: flowpaths to progress. Ecology 85:2369-2379.

Giesler, R., M. Högberg, and P. Högberg. 1998. Soil chemistry and plants in Fennoscandian boreal forest as exemplified by a local gradient. Ecology 79:119-137.

Grabs, T. J., K. G. Jencso, B. L. McGlynn, and J. Seibert. 2010. Calculating terrain indices along streams: A new method for separating stream sides. Water Resources Research 46:W12536.

Hanski, I. 1999. Metapopulation ecology. Oxford University Press, Oxford, UK.

Harner, M. J., and J. A. Stanford. 2003. Differences in cottonwood growth between a losing and a gaining reach of an alluvial floodplain. Ecology 84:1453-1458.

Hill, A. R. 1996. Nitrate removal in stream riparian zones. Journal of Environmental Quality 25:743-755.

Högberg, M. N., E. Bååth, A. Nordgren, K. Arnebrant, and P. Högberg. 2003. Contrasting effects of nitrogen availability on plant carbon supply to mycorrhizal fungi and saprotrophs: a hypothesis based on field observations in boreal forest. New Phytologist 160:225-238.

Högberg, P. 1997. Tansley Review No. 95: ${ }^{15} \mathrm{~N}$ natural abundance in soil-plant systems. New Phytologist 137:179203.

Hupp, C. R., and W. R. Osterkamp. 1985. Bottomland vegetation distribution along Passage Creek, Virginia, in relation to fluvial landforms. Ecology 66:670-681.

Hynes, H. B. N. 1975. The stream and its valley. Verhandlungen der Internationale Vereinigung fur Theoretische und Angewandte Limnologie 19:1-15.

Jansson, R., H. Laudon, E. Johansson, and C. Augspurger. 2007. The importance of groundwater discharge for plant species number in riparian zones. Ecology 88:131-139.

Jenson, S. K., and J. O. Domingue. 1988. Extracting topographic structure from digital elevation data for geographic information-system analysis. Photogrammetric Engineering and Remote Sensing 54:1593-1600.

Kopecký, M., and Š. Č́žková. 2010. Using topographic wetness index in vegetation ecology: does the algorithm matter? Applied Vegetation Science 13:450-459.

Krok, T. O. B. N., and S. Almquist. 1994. Svensk flora. Fanerogamer och Ormbunksväxter. 27th edition. Liber Utbildning, Stockholm, Sweden.

Laudon, H., M. Berggren, A. Ågren, I. Buffam, K. Bishop, T. Grabs, M. Jansson, and S. Köhler. 2011. Patterns and dynamics of dissolved organic carbon (DOC) in boreal streams: The role of processes, connectivity, and scaling. Ecosystems 14:880-893.

Legendre, P. 1993. Spatial autocorrelation: trouble or new paradigm? Ecology 74:1659-1673.

Leibold, M. A., et al. 2004. The metacommunity concept: a framework for multi-scale community ecology. Ecology Letters 7:601-613.

Lite, S. J., K. J. Bagstad, and J. C. Stromberg. 2005. Riparian plant species richness along lateral and longitudinal gradients of water stress and flood disturbance, San Pedro River, Arizona, USA. Journal of Arid Environments 63:785-813.

Luke, S. H., N. J. Luckai, J. M. Burke, and E. E. Prepas. 2007. Riparian areas in the Canadian boreal forest and linkages with water quality in streams. Environmental Reviews 15:7997.

Lyon, S. W., T. Grabs, H. Laudon, K. H. Bishop, and J. Seibert. 2011. Variability of groundwater levels and total organic carbon in the riparian zone of a boreal catchment. Journal of Geophysical Research-Biogeosciences 116: G01020.

Merritt, D. M., M. L. Scott, N. L. Poff, G. T. Auble, and D. A. Lytle. 2010. Theory, methods and tools for determining environmental flows for riparian vegetation: riparian vegetation-flow response guilds. Freshwater Biology 55: $206-225$.

Naiman, R. J., and H. Décamps. 1997. The ecology of interfaces: Riparian zones. Annual Review of Ecology and Systematics 28:621-658.

Nilsson, C. 1987. Distribution of stream-edge vegetation along a gradient of current velocity. Journal of Ecology 75:513522 . 
Nilsson, C., R. L. Brown, R. Jansson, and D. M. Merritt. 2010. The role of hydrochory in structuring riparian and wetland vegetation. Biological Reviews 85:837-858.

Poff, N. L., J. D. Allan, M. B. Bain, J. R. Karr, K. L. Prestegaard, B. D. Richter, R. E. Sparks, and J. C. Stromberg. 1997. The natural flow regime. Bioscience 47: 769-784.

Polvi, L. E., E. E. Wohl, and D. M. Merritt. 2011. Geomorphic and process domain controls on riparian zones in the Colorado Front Range. Geomorphology 125:504-516.

R Development Core Team. 2011. R: a language and environment for statistical computing. $\mathrm{R}$ Foundation for Statistical Computing, Vienna, Austria.

R Development Core Team. 2013. R: a language and environment for statistical computing. R Foundation for Statistical Computing, Vienna, Austria.

Renöfält, B. M., C. Nilsson, and R. Jansson. 2005. Spatial and temporal patterns of species richness in a riparian landscape. Journal of Biogeography 32:2025-2037.

Richardson, J. S., R. J. Naiman, and P. A. Bisson. 2012. How did fixed-width buffers become standard practice for protecting freshwaters and their riparian areas from forest harvest practices? Freshwater Science 31:232-238.
Sabater, S., et al. 2003. Nitrogen removal by riparian buffers along a European climatic gradient: Patterns and factors of variation. Ecosystems 6:20-30.

Shoutis, L., D. T. Patten, and B. McGlynn. 2010. Terrain-based predictive modeling of riparian vegetation in a northern Rocky Mountain watershed. Wetlands 30:621-633.

Strahler, A. N. 1957. Quantitative analysis of watershed geomorphology. Transactions, American Geophysica Union 38:913-920.

Ström, L., R. Jansson, and C. Nilsson. 2012. Projected changes in plant species richness and extent of riparian vegetation belts as a result of climate-driven hydrological change along the Vindel River in Sweden. Freshwater Biology 57:49-60.

Wiens, J. A. 2002. Riverine landscapes: taking landscape ecology into the water. Freshwater Biology 47:501-515.

Wright, S. 1921. Correlation and causation. Journal of Agricultural Research 20:557-585.

Zinko, U., M. Dynesius, C. Nilsson, and J. Seibert. 2006. The role of soil $\mathrm{pH}$ in linking groundwater flow and plant species density in boreal forest landscapes. Ecography 29:515-524.

Zinko, U., J. Seibert, M. Dynesius, and C. Nilsson. 2005. Plant species numbers predicted by a topography-based groundwater flow index. Ecosystems 8:430-441.

\section{Supplemental Material}

\section{Appendix A}

A table showing properties and number of selected sites for each stream size class (Ecological Archives E095-059-A1).

\section{Appendix B}

A figure showing the differences in species richness between groundwater (GW) discharge and non-discharge sites along all stream size classes displayed separately for till and sedimentary streams (Ecological Archives E095-059-A2).

\section{Appendix C}

A path analysis of direct and indirect effect of $\mathrm{GW}$, soil $\mathrm{pH}$, and $\mathrm{C} / \mathrm{N}$, and stream size and type on species richness of riparian plant communities in the Krycklan catchment (Ecological Archives E095-059-A3).

\section{Appendix D}

A summary table of differences in environmental variables between sediment and till-dominated streams (Ecological Archives E095-059-A4). 